\section{Hazard perception and possi- bility of simplifying food safety management systems in small businesses in Piedmont region, Italy}

\author{
Leonardo A. Ceballos, ${ }^{1}$ \\ Davide Vercellino, ${ }^{1,2}$ Valeria D'Errico, ${ }^{1,3}$ \\ Paola Barzanti, ${ }^{1}$ Lucia Decastelli, ${ }^{1}$ \\ Luca Nicolandi, ${ }^{4}$ Mauro Negro, ${ }^{5}$ \\ Giuseppe Ru${ }^{1}$ \\ ${ }^{1}$ Experimental Zooprophylactic Institute \\ of Piedmont, Liguria and Aosta Valley, \\ Turin; ${ }^{2}$ Hygiene Service for Livestock \\ and Zootechnical Production, ASL AT, \\ Asti; ${ }^{3}$ Service for Animal Health, ASL \\ TO5, Turin; ${ }^{4}$ Hygiene Service for \\ Livestock and Zootechnical Production, \\ ASL TO4, Turin; ${ }^{5}$ Hygiene Service for \\ Food of Animal Origin, ASL CN1, \\ Cuneo, Italy
}

\section{Abstract \\ Small food businesses, because of their} limited resources, are hard pressed to comply with the requirements of a conventional food safety management system (FSMS). To overcome it, the European legislation provides some flexibility in the application of FSMS. With this study, we evaluated the change in the perception and awareness of hazards in food production and in the attitudes of food business operators (FBOs) after a regional regulation was introduced to allow flexibility and a campaign of training activities on the FSMS simplification opportunities. Training activities targeting various stakeholders have been carried out in Piedmont region since 2014. A total of 283 FBOs from the dairy and the meat supply chains were recruited for a two-round survey. Overall, the majority of the FBOs believed that application of an FSMS helps to overcome official controls, to produce healthy foods, to better manage the production process, and for staff training; its usefulness for enhancing customer trust was judged of limited value. FBO knowledge on the possibility of simplifying the FSMS activities increased significantly between surveys, suggesting the success of the information campaigns. Over time, simplification increased in the meat but not in the dairy supply chain, where it involved nearly $70 \%$ of FBOs. The cost of FSMS (mainly due to microbiological analysis) and the time it takes were the main reasons for FBO resistance to its application. Simplification of FSMS procedures were welcomed by the vast majority $(>90 \%)$ of FBOs. The perception of hazards was low and generic, suggesting the need for targeted training activities.

\section{Introduction}

The core of current European food safety legislation, the so-called Food Hygiene Package (EC, 2004a-c), went into effect in January 2006. Accordingly, food businesses had to change their approach to food hygiene, implementing a food safety management system (FSMS) (EC, 2004a). The main changes were: i) primary legal responsibility for ensuring food safety borne by the food business operator (FBO); ii) general implementation of food safety procedures based on the principles of Hazard Analysis and Critical Control Points (HACCP). This new approach demanded huge effort by FBOs to convert their internal control procedures for food safety. Preparing, implementing, and maintaining a permanent procedure based on HACCP principles in strict mode do not seem to be sustainable by small food businesses (SFB) (e.g., butchers, food retailers) due to the limited availability of human, financial, and technical resources (Panisello and Quantick, 2001; Taylor and Kane, 2005; FAO, 2006; Yapp and Fairman, 2006; Violaris, 2008; Karabasil et al., 2015). To overcome these difficulties, the Food Hygiene Package grants flexibility measures that make it possible to simplify the FSMS, i.e., waivers and adaptations of certain requirements set forth in the regulations (EC, 2016). A factfinding mission mandated by the European Commission revealed that the level of application of flexibility measures by small establishments differed widely across European Member States considered (EC, 2011). Furthermore, it was observed that "establishments and their operations showed more deficiencies where national measures for flexibility were not available". To the best of our knowledge, no study has been published at the regional or national level regarding how widespread it is the application of flexibility in Italy. The Italian federal legal status makes it possible for each Regional government to apply flexibility with regional regulations. In Piedmont region, northwest of Italy, the authority introduced a certain degree of simplification for FSMS requirements in SFB, particularly as concerns compulsory record keeping and microbiological analyses, with which FBOs document the effectiveness of their FSMS (Piedmont Region, 2012), and which must be commensurate with the nature and the size of the food business. This regional
Correspondence: Leonardo A. Ceballos, S.S. Biostatistics, Epidemiology and Risk Analysis Experimental Zooprophylactic Institute of Piedmont, Liguria and Aosta Valley, Turin, Italy.

Tel.: +39.011.2686371

E-mail: leonardo.ceballos@izsto.it.

Key words: Small food business, Hazards perception, HACCP, Simplification, Food safety.

Acknowledgments: The authors wish to thank S. Gallina, A. Bellio, M. Caputo, and M. Cravero, who contributed to the project; special thanks to G. Corgiat Loia for the official support of the Region of Piedmont. We also thank all the FBOs for their kind participation in the interviews.

Contributions: LC, data collection, analysis, manuscript write-up; DV, study design, data collection, analysis and drafting the manuscript; VD, data collection; $\mathrm{PB}$, study design and revision of the manuscript; $\mathrm{LD}$, carrying out training activities and revision of the manuscript; LN, conception and design of the study, carrying out training activities; $\mathrm{MN}$, carrying out training activities and revision of the manuscript; GR, design and supervision of the entire project, and finalizing the manuscript. All the authors commented on the manuscript and approved the final version. LAC and DV contributed equally to this work.

Conflict of interests: The authors declare no potential conflict of interests.

Funding: Italian Ministry of Health, grant IZSPLV21/12RC to G. Ru.

Availability of data and materials: The data that support the findings of this study are available from the corresponding author upon reasonable request.

Ethics approval and consent to participate: This research was conducted in accordance with all relevant guidelines and procedures.

Consent for publication: The manuscript does not contain any individual person's data in any form.

Received for publication: 7 May 2019 Revision received: 23 December 2019. Accepted for publication: 23 December 2019.

This work is licensed under a Creative Commons Attribution-NonCommercial 4.0 International License (CC BY-NC 4.0).

(C) Copyright: the Author(s), 2020

Licensee PAGEPress, Italy

Italian Journal of Food Safety 2020; 9:8273

doi:10.4081/ijfs.2020.8273

initiative provided the possibility: i) for certain SFB to skip identification of Critical Control Points, replaced by Good Hygienic 
Practices; ii) to record non-compliance events only (i.e., recording by exception) in relation to the Prerequisite Programme; and iii) to reduce the number of sample units for analysis necessary to verify compliance of food products with the microbiological criteria set forth under European regulation (EC, 2005b). However, based on the experience of the authors, at the time when this study was conceived many FBOs were not aware of the possibility of carrying out a simplified FSMS.

A project with the general aim of improving the application of FSMS in local SFB started in 2010 (Nicolandi et al., 2011a,b, 2012). It included training activities for both FBOs and officers of the National Health Service Agency who perform the official controls. The aim of these activities was to activate a widespread information cascade in the Region that could reach, directly or indirectly, the final recipients (i.e., the FBOs). In this framework, we conducted surveys to measure and compare the changes in perception and awareness of hazards in food production and the attitudes of FBOs after the regulatory intervention allowing simplification went into effect, and to assess the overall effectiveness of the official training activities on FSMS simplification opportunities, implemented since 2014.

\section{Materials and Methods}

\section{Study design}

A training intervention to the SFB in general was combined with periodic representative surveys to indirectly monitor its impact and effectiveness. The study was conducted on a regional scale (Piedmont) over a 36-month period (2014-2017).

The target companies to be surveyed were randomly selected according to criteria that define a small business, i.e., an enterprise that employs not more than 10 persons with an annual turnover and/or total annual balance of up to $€ 2$ million (EC, 2003). The study activities have been focused on SFB operating on three different food chains: dairy (dairy companies), meat (butchers' shops and meat producers) and public catering (bars and restaurants). By November 2014 the Piedmont Region had registered about 400 dairy, 500 meat, and 26,000 public catering SFB. The results regarding the public catering chain will be presented in a separate publication because of the disparity in numbers, the greater heterogeneity of businesses, products and services, and the much higher ratio of FBOs to agency control officers than in the dairy and meat sectors.

\section{Training activities}

The regional training activities included instruction in reorientation interventions in which the priorities and forms of FSMS simplification were presented to the FBOs, as well as the proportional actions of the agency control officers. Working groups composed of National Health Service veterinarians, food inspectors, and epidemiologists were formed to devise criteria and guidelines for simplifying FSMS procedures and application of official controls in a consistent and standardized manner. Moreover, based on the FBOs' training needs (need to address the gap between perception and knowledge of food production hazards) identified in a previous study (Nicolandi et al., 2011a,b), informative and training materials were created for different stakeholder categories (FBOs, agency control officers, food business consultants, and members of FBO trade associations).

\section{Two-round survey}

We performed two surveys, one in 2015 $\left(t_{0}\right)$ and again in $2017\left(t_{1}\right)$. For each food supply chain, a random sample of SFB was obtained from the regional registry after stratifying by health district (i.e., the geographic units of the Italian National Health Service, where a local agency is responsible for official controls on food safety). The surveys consisted of telephone interviews using a questionnaire (a copy is available from the corresponding author upon request) composed of four sections: i) general information about the business activity; ii) perceptions of food-associated hazards; iii) opinions on usefulness and difficulties in the application of an FSMS; and iv) knowledge and application of flexibility measures. Regarding Section 3 (usefulness and difficulty in applying an FSMS), a set of questions with structured answers investigated the reasons why an FSMS was considered useful (i.e., preparation for official controls, guarantee of healthy food, assistance in organizing the production process, staff training, and increased customer confidence). Further information was collected on three specific procedures considered likely associated with the difficulties encountered in applying an FSMS (staff training, waste management and by-products processing, and food or environmental microbiological analysis).

The FBOs were sent a letter from the regional agency about 15 days before the telephone contact to inform them about the survey and its goals and to invite them to participate. A pre-survey test of the questionnaire was conducted with five randomly sampled FBOs per food supply chain. The questionnaire was adjusted according to the test responses.

\section{Statistical analysis}

Statistical analysis was performed using STATA 14 (StataCorp, 2015). Separately for each food supply chain, the chi-square $\left(\chi^{2}\right)$ test was used to determine whether there were differences in survey questionnaire responses between $t_{0}$ and $t_{1}$.

Likewise, we analyzed the relationship between the perception of food-associated hazards and the respondents' educational level and the application of staff training procedures. For this analysis, the variables were grouped as follows: 'hazards perception' was aggregated in three answer categories (specific hazard, non-specific hazard or "Don't know"); the "educational level' in four categories (primary, secondary, high school, and college degree), and the 'staff training procedure' in three categories of application (easy, with some difficulties, not applied). A multivariate logistic regression model was used to analyze the factors that favor the adhesion to the opportunity to simplify the FSMS. For this purpose, the item 'implementation of FSMS simplification' (YES/NO) was a dichotomous dependent variable and the following items were potentially predictive variables: age and educational level (only when the respondent was the business owner), food supply chain, number of employees, year the activity business started, and knowledge of the regional official control guidelines. Statistical significance was set at 0.05 . Except for the items investigating knowledge of food-associated risks, the "Don't know" responses were excluded from analysis.

\section{Results}

\section{Training programs}

In all, 16 training courses were carried out between 2014 and 2017. Twelve of these courses were addressed to FBOs (400 participants) and 4 to agency control officers, food sector technicians and external consultants (196 participants). Seven events specifically targeted the dairy supply chain (43\% of all participants) and the remaining were addressed to all FBOs.

\section{The surveys}

We interviewed a total of 283 FBOs: 149 from the meat supply chain (respondents: $t_{0}=$ $78, t_{1}=71$; response rate: $t_{0}=88 \%, t_{1}=85 \%$ ) and 134 from the dairy supply chain $\left(t_{0}=72\right.$, $\left.t_{1}=62 ; t_{0}=95 \%, t_{1}=91 \%\right)$. 
General characteristics of the FBOs

Sixty-nine percent of sampled SFB in the meat chain and $78 \%$ of those in the dairy supply chain had a maximum of 3 employees (average for all SFB) and over $90 \%$ of SFB had a maximum of 5 employees. At least one family member worked in over $76 \%$ of the SFB in either food supply chain. Business owners accounted for $77 \%$ of the interviewees operating in the meat and $79 \%$ in the dairy supply chain. The average age was 49 years; $45 \%$ had a high school diploma and $8 \%$ a college degree. More than $70 \%$ of the businesses $(79 \%$ for meat chain, $71 \%$ for dairy chain) started the activity before 2006 , the year the Food Hygiene Package went into force.

Eighty-three percent of the dairy chain FBOs and $64 \%$ of meat chain FBOs stated they belonged to a business trade association ( $\chi^{2}$ test: $\mathrm{P}=0.002$ ). Only one FBO declared not having an FSMS in place and around $80 \%$ said they relied on an external consultant to write it.

Perception of food-associated hazards

In both surveys, FBOs in both food supply chains indicated biological hazards as those of greatest health relevance, followed by chemical hazards. Physical hazards were considered the least relevant (Table 1). Some $19 \%$ of the respondents were unable to define the nature of a potential hazard to consumer health; many respondents $(61 / 133$ at $t_{1}$ ) mentioned only generic sources (e.g., interruption of the cold chain instead of bacterial growth).

Although the percentage of FBOs indicating the importance of biological hazards decreased between the two surveys, the ranking of hazards did not vary (Table 1). For the meat supply chain, however, the ratio between the perception associated with respectively biological or chemical hazards and that associated with physical hazards varied between surveys. The ratio between biological and physical hazards increased from about $10\left(t_{0}=67 / 7\right)$ to $48\left(t_{l}=48 / 1\right)$ and the ratio between chemical and physical hazards from about $4\left(t_{0}=25 / 7\right)$ to about 15 $\left(t_{l}=15 / 1\right)$ (Table 1).

Perception was also positively associated with the respondents' educational level and the application of staff training procedures $\left(\chi^{2}\right.$ test: $\mathrm{P}<0.001$ and $\mathrm{P}=0.011$, respectively).

\section{Opinion about the FSMS}

The majority of the FBOs believed that the FSMS is useful in general or at least in part (responses "Yes" or "Yes, only partially") to address official controls (minmax: $83-97 \%$ ), to produce healthy food (84-92\%), to better manage the production process $(72-84 \%)$, and to provide staff training (74-91\%). The usefulness of FSMS as a tool for enhancing customer trust was judged as having limited value (min-max: 45-64\%) (Table 2). While there were no significant changes between the two surveys for the dairy chain FBOs, we observed significant differences for the meat chain. In particular, there was a decrease in positive opinion on the usefulness of the FSMS to overcome official controls, to provide staff training, and to increase customer trust (Table 2).

\section{Difficulties in application of the FSMS}

Responses regarding the items investigating the difficulties the FBOs

Table 1. Percentage (CI95\%) of food business operators who reported hazards potentially associated with food by type of hazard, food supply chain, and survey year $\left(t_{0}: 2015, t_{1}: 2017\right)$. In total, data from 283 interviews.

\begin{tabular}{|c|c|c|c|c|c|c|}
\hline \multirow{2}{*}{$\begin{array}{l}\text { Supply chain } \\
\text { Hazard reported }\end{array}$} & \multirow{2}{*}{\multicolumn{2}{|c|}{$\begin{array}{c}\text { Meat } \\
t_{1}\end{array}$}} & & \multicolumn{3}{|c|}{ Dairy } \\
\hline & & & $t_{0}+t_{1}$ & $t_{0}$ & $t_{1}$ & $t_{0}+t_{1}$ \\
\hline Biological & $\begin{array}{c}85.9 \mathrm{a} \\
(76.0-92.1)\end{array}$ & $\begin{array}{c}67.6^{\mathrm{a}} \\
(55.6-77.6)\end{array}$ & 77.2 & $\begin{array}{c}63.9 \mathrm{a} \\
(51.9-74.3)\end{array}$ & $\begin{array}{c}45.2^{\mathrm{a}} \\
(33.0-57.9)\end{array}$ & 55.2 \\
\hline Chemical & $\begin{array}{c}32.1 \\
(22.5-43.4)\end{array}$ & $\begin{array}{c}21.1 \\
(13.0-32.4)\end{array}$ & 26.9 & $\begin{array}{c}36.1 \\
(25.7-48.1)\end{array}$ & $\begin{array}{c}33.9 \\
(23.0-46.8)\end{array}$ & 35.1 \\
\hline Physical & $\begin{array}{c}9.0^{\mathrm{a}} \\
(4.3-17.9)\end{array}$ & $\begin{array}{l}1.4^{\mathrm{a}} \\
(0.1-9.7)\end{array}$ & 5.4 & $\begin{array}{c}12.5 \\
(6.5-22.6)\end{array}$ & $\begin{array}{c}9.7 \\
(4.3-20.3)\end{array}$ & 11.2 \\
\hline Don't know & $\begin{array}{c}6.4^{\mathrm{b}} \\
(2.6-14.7)\end{array}$ & $\begin{array}{c}15.5^{\mathrm{b}} \\
(8.7-26.2)\end{array}$ & 10.7 & $\begin{array}{c}22.2 \\
(13.9-33.5)\end{array}$ & $\begin{array}{c}33.9 \\
(23.0-46.8)\end{array}$ & 27.6 \\
\hline No. interviews & 78 & 71 & 149 & 72 & 62 & 134 \\
\hline
\end{tabular}

${ }^{\mathrm{a}} \chi^{2}$ test $\left(t_{0}\right.$ vs $\left.t_{1}\right), \mathrm{P}<0.05 ; \mathrm{b}<0.1$.

Table 2. Percentage (CI95\%) of positive opinion ("Yes" and "Yes, only partially" responses combined) of food business operators by supply chain and survey year $\left(t_{0}: 2015, t_{1}: 2017\right)$ on the usefulness of the food safety management system (FSMS). "Don't know" responses were not included in the analysis.

\begin{tabular}{|c|c|c|c|c|c|c|}
\hline \multirow{2}{*}{$\begin{array}{l}\text { Supply chain } \\
\text { Hazard reported }\end{array}$} & \multicolumn{3}{|c|}{ Meat } & \multicolumn{3}{|c|}{ Dairy } \\
\hline & $t_{0}$ & $t_{1}$ & $t_{0}+t_{1}$ & $t_{0}$ & $t_{1}$ & $t_{0}+t_{1}$ \\
\hline Is FSMS useful for preparing for official controls? & $\begin{array}{c}93.5^{\mathrm{a}} \\
(85.1-97.3)\end{array}$ & $\begin{array}{c}83.1^{\mathrm{a}} \\
(72.2-90.3)\end{array}$ & 88.5 & $\begin{array}{c}90.1 \\
(80.4-95.3)\end{array}$ & $\begin{array}{c}96.7 \\
(87.4-99.2)\end{array}$ & 93.2 \\
\hline Does the FSMS give more guarantees to produce healthy food? & $\begin{array}{c}84.4 \\
(74.3-91.0)\end{array}$ & $\begin{array}{c}91.5 \\
(82.1-96.2)\end{array}$ & 87.8 & $\begin{array}{c}91.7 \\
(82.4-96.3)\end{array}$ & $\begin{array}{c}88.7 \\
(77.8-94.6)\end{array}$ & 90.3 \\
\hline Does the FSMS help to better manage the production phases? & $\begin{array}{c}82.9 \\
(72.5-89.9)\end{array}$ & $\begin{array}{c}73.9 \\
(62.0-83.1)\end{array}$ & 78.6 & $\begin{array}{c}72.2 \\
(60.5-81.5)\end{array}$ & $\begin{array}{c}83.6 \\
(71.7-91.1)\end{array}$ & 77.4 \\
\hline Is FSMS useful for staff training? & $\begin{array}{c}90.9^{\mathrm{a}} \\
(81.9-95.7)\end{array}$ & $\begin{array}{c}73.8^{\mathrm{a}} \\
(61.5-83.3)\end{array}$ & 83.1 & $\begin{array}{c}73.5 \\
(61.5-82.8)\end{array}$ & $\begin{array}{c}80.0 \\
(67.6-88.5)\end{array}$ & 76.6 \\
\hline Does FSMS increase customer trust? & $\begin{array}{c}63.5^{\mathrm{a}} \\
(51.7-73.9)\end{array}$ & $\begin{array}{c}45.3^{\mathrm{a}} \\
(33.3-57.9)\end{array}$ & 55.1 & $\begin{array}{c}59.7 \\
(47.3-71.0)\end{array}$ & $\begin{array}{c}56.9 \\
(43.6-69.3)\end{array}$ & 58.4 \\
\hline
\end{tabular}

${ }^{a} \chi^{2}$ test $\left(t_{0} v s t_{1}\right), \mathrm{P}<0.05 ; \mathrm{b}<0.1$. 
encountered in applying the FSMS had great diversity (Table 3). In general, when applied, about half of the FBOs believed that staff training is easy to carry out; but when it is viewed as a problem, it is seen as time taken away from production and resulting in a "cost", in terms of minor potential profit.

Waste management was perceived as an easy procedure to perform. However, its cost was more important issue for the meat than for the dairy supply chain operators $\left(\chi^{2}\right.$ test: $\mathrm{P}<0.001)$. Most of the dairy operators either did not consider waste management a critical matter or they did not apply the procedure.

For the FBOs in both food supply chains, the microbiological analysis procedure is the one that most clearly represented a cost problem; in particular, the percentage of dairy supply chain FBOs that perceived the cost of the analysis as a difficulty increased significantly between $t_{0}$ and $t_{1}\left(+23 ; \chi^{2}\right.$ test: $\left.\mathrm{P}=0.01\right)$.

Interpretation of legislation did not seem to be a widespread difficulty for the FBOs (Table 3).

\section{Knowledge and implementation of flexibility measures}

Overall knowledge of the possibility to simplify application of the FSMS increased from 41 to $63 \%\left(\chi^{2}\right.$ test: $\left.\mathrm{P}<0.001\right)$ between surveys. The increase was greater for the dairy ( 35 to $63 \% ; \mathrm{P}=0.001$ ) than for the meat supply chain FBOs (46 to $63 \% ; \mathrm{P}=0.035$ ) (Figure 1). The percentage of FBOs that adhered to the simplification measures between 2015 and 2017 increased for the meat ( 47 to $69 \%$; $\mathrm{P}<0.05$ ) but not for the dairy supply chain, where it was already widely applied (68 to $67 \%$; $>>0.91$ ) (Figure 1). Multivariate analysis showed that a smaller number of employees (odds ratio $[\mathrm{OR}]=0.21,95 \%$ confidence interval $[\mathrm{CI}]=$ $0.05-0.87)$ and knowledge of the regional official control guidelines $(\mathrm{OR}=0.41,95 \%$
$\mathrm{CI}=0.20-0.84)$ were positive factors for adoption of a simplified FSMS, whereas no association was found for educational level (grouped in two categories: primary and secondary school vs. high school and college degree), owner age, start year of the business (grouped in two categories: before and after 2006, the year the Food Hygiene Package went into force), and type of food supply chain.

Among the respondents who stated they knew about the simplification, we observed a non-significant increase in the percentage of those that identified it as a real opportunity (responses "Yes" or "Yes, only partially") to reduce the burdens required by FSMS implementation $\left(t_{0}=77 \%, t_{1}=84 \%\right.$; $\chi^{2}$ test: $\left.\mathrm{P}=0.39\right)$. Moreover, there was a decrease in the percent of FBOs that did not know whether the simplification would result in a concrete reduction in obligations (response "Don't know": $t_{0}=18 \%$ to $t_{1}=5 \%$; $\mathrm{P}=0.02$ ), with a non-significant increase in negative responses (response "No": $5 \%$ to $11 \% ; \mathrm{P}=0.32$ ).

Restricting the analysis only to the FBOs that stated they had simplified their FSMS (i.e., who had a standard full HACCP-based system before simplification), we observed a greater proportion of FBOs that identified this opportunity as positive, both overall $\left(t_{0}=\right.$ $\left.94 \%, t_{1}=93 \%\right)$ and by supply chain $(88-$ $100 \%$ ), without significant differences between surveys.

The main channels through which the FBOs were informed about the possibility to simplify FSMS implementation were, in order of importance and without being mutually exclusive, the regional agency

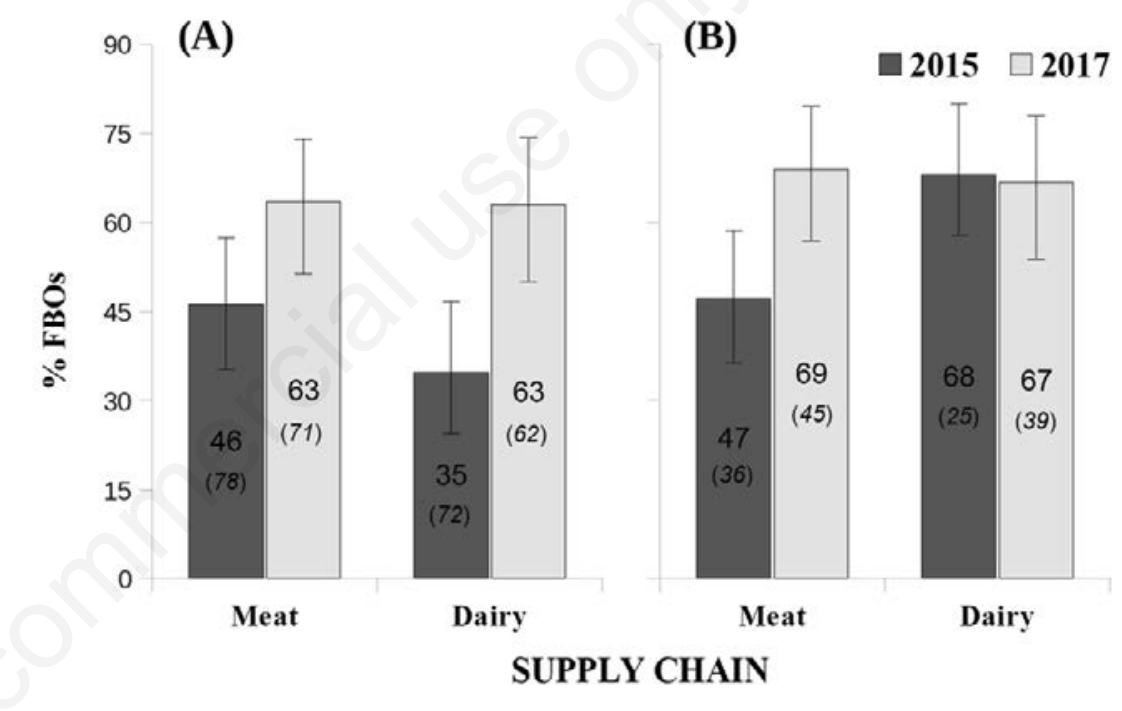

Figure 1. Percentage of food business operators (FBOs) that know of the possibility to simplify the food safety management system (A) and percentage of operators by supply chain and survey year who actually applied simplification (B). Number of respondents is given in parenthesis.

Table 3. Percentage of operators by supply chain and survey year $\left(t_{0}: 2015, t_{1}: 2017\right)$ who reported or not a specific difficulty in the application of certain food safety management system procedures.

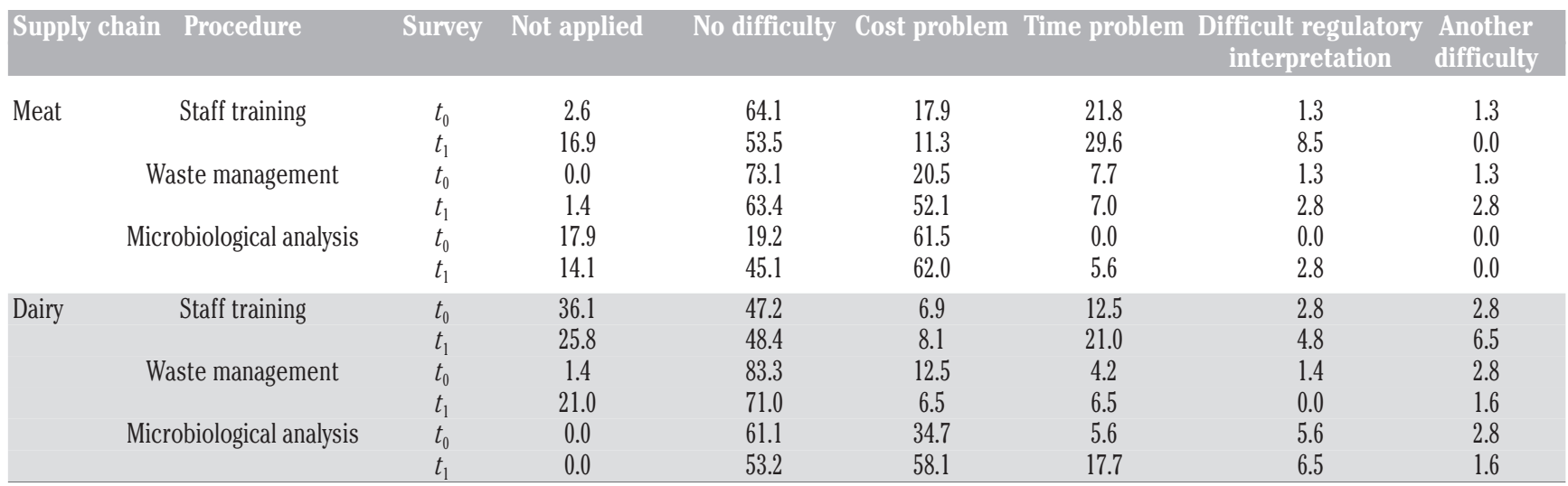


(70\%), food business consultants $(23 \%)$, trade associations $(10 \%)$, and the internet (4\%). Exchange of information between colleagues and training courses were also mentioned ( $6 \%$ of respondents).

\section{Discussion}

Our two-round survey of SFB operators belonging to the meat and the dairy supply chain provides a picture of their perception of the usefulness of an FSMS and the potential hazards to consumer health. Our results show that, during the three years in which information and training interventions were provided, increased the awareness of the issue of simplification and of the advantages associated with it. Because of the diffuse nature of the interventions we were unable to identify a (non-trained) control group and carry out a difference-indifference (DID) study. Despite this methodological limitation, there is no apparent reason that explains whether a similar effect could have occurred in the absence of targeted interventions: the responses of the two representative samples of FBOs showed that the role of the internet or other information sources was marginal as compared with that of the information cascade managed by the competent agencies and the food business consultants.

\section{Awareness of health hazards}

It was not possible for the FBOs to conciliate simplification and food safety in the absence of a solid knowledge of the hazards of their production chain. For the implementation of the simplified FSMS, unlike the standard full HACCP, the FBOs need only to be aware that a hazard (or 'group of hazards') may occur at a particular stage of the production and that its occurrence can be prevented or facilitated/promoted by performing certain activities or not (EFSA, 2017). For example, the FBO should know that the concentration of pathogenic bacteria will increase if the conditions of refrigeration and cleaning are not adequate, no matter what species of bacteria it might be. From this point of view, our surveys indicate that the operators were mainly concerned about biological hazards: it is unclear whether this is the result of risk assessment or rather of a limited knowledge of other types of hazards. Conversely, unlike the previous survey (Nicolandi et al., 2011a,b, 2012) and other studies (e.g., Panisello et al., 1999), physical hazards, in some way more apparent than other types of hazards, were the least mentioned, especially for the dairy supply chain operators. This could indicate that increasing attention is being directed towards the less "visible" but potentially more insidious hazards (i.e., biological and chemical hazards). Also, based on the experience in official controls, there is a high number of FBOs not including physical hazards in hazard analysis or not following correctly all necessary steps in the implementation of their procedures based on HACCP principles. Thus, there should be more focus on physical hazards from competent authorities; producers might not have all the necessary knowledge to carry out thorough hazard analysis.

Moreover, a noteworthy percentage of respondents were either unable to answer or responded generically when they were asked to rank the hazard based on its nature, confusing the technical meaning of hazard, as defined within the HACCP frame, with the broader one of "generic source of hazard". This misconception, at least as concerns biological hazards, likely stems from a limited knowledge of pathogens and the foods associated with them - as evidenced by Angelillo et al. (2000) for other areas in Italy. Given the close relationship that exists between knowledge, attitude, and HACCP practices (Ko, 2013) and the association between food hazard identification and staff education and training (Fielding et al., 2005; Violaris et al., 2008), our results indicate the need to invest energy and resources to bridge these knowledge gaps. However, knowledge per $s e$ of the hazards and of the measures necessary to effectively address them is not necessarily sufficient to produce a change in attitude and practices in food production and handling (Zanin et al., 2017). Therefore, effective education in food safety should be designed appropriately to bring about behavior change and practical implementation of effective measures (Thaivalappil et al., 2018).

\section{Awareness of the usefulness of the FSMS and difficulty in its imple- mentation}

The FBOs demonstrated good awareness of the usefulness of the FSMS for business management. The respondents stated that this tool is especially useful to comply with legal requirements and to successfully pass official controls, and to a lesser extent to guarantee food safety. In comparison with a previous study (Nicolandi et al., 2011a,b), the FBOs in the meat and dairy supply chains showed an increase in awareness, especially regarding the issue of food safety. Instead, the idea that the FSMS can be useful to promote their products in the eyes of the consumer has not been consolidated yet. From this point of view, the FBOs would be more motivated to apply FSMS if they were sure that it might boost the promotion of food quality and consumer trust. This awareness is difficult to disseminate, as shown in a previous survey (Nicolandi et al., 2011a,b).

The difficulties reported by the FBOs in FSMS application varied by supply chain depending on the chains' productive peculiarities, but in general were consistent with those reported in the literature (EFSA, 2017). For example, staff training, in general, was not seen as a difficulty by family-run SFB, particularly those in the dairy chain. Among these operators, also the management of waste and processing byproducts did not represent a major difficulty, probably because the main by-product of processing, i.e. the serum, can be easily recycled on the farm as animal feed. Conversely, this procedure clearly affects costs for the meat chain in terms of byproduct collection and disposal (i.e., bones, hair, hooves, fat, feathers, etc.). For both food supply chains, the cost of microbiological analysis was the main difficulty. In this regard, it would be important to provide the operators with information on how to reduce the frequency and number of samples for microbiological analysis according to specific production contexts. Moreover, in line with observations by Henson et al. (1999), the time needed for carrying out FSMS activities has been repeatedly reported as a difficulty, confirming the importance of simplification and the opportunities that it offers the FBOs, either directly by facilitating certain procedures, or indirectly by releasing time from some procedures to concentrate efforts on those of greater health value.

\section{Knowledge and implementation of FSMS simplification}

Simplification of FSMS provided by the Piedmont guidelines met with a broadly favorable response by the interviewed FBOs. It was particularly appreciated by those who actually applied it, reducing the recordkeeping activities and the frequency of microbiological analysis, thus saving time and money. The earlier and wider implementation of FSMS simplification by the dairy supply operators is likely due to a higher number of interventions conducted specifically to this supply chain.

Nevertheless, greater knowledge did not result in a larger proportion of adhesion, suggesting a time delay between these. On the other hand, given the high percentage of FBOs that replied that simplification is a concrete opportunity to lighten FSMSassociated obligations, the residual percentage of non-adherence is unlikely due to an insufficiently attractive chance to 
simplify the procedures. A possible alternative explanation is that a plateau in adhesion has been reached, as suggested by the FBOs in the dairy supply chain where adhesion has remained around $70 \%$ for both surveys. This could reflect a specific requirement of a group of FBOs who apply the full HACCP system because they are included in the large-scale distribution or connected to export, i.e., for commercial factors. Also, some FBOs might have no interest in applying a simplified FSMS because they are comfortable with the system they are already using and prefer to document their activity in more detail. Another determinant of non-adhesion could be a "natural" resistance to change, although our results showed no relationship between adherence to the possibility of simplification and the age and level of education of the business owner. Other factors - social, psychological, and experience - besides the knowledge of the opportunity to simplify implementation of FSMS may shape the FBOs' identity and their modus operandi.

As mentioned above, a smaller number of employees and knowledge of the regional official guidelines were positive factors for the adoption of a simplified FSMS. The number of employees may be related to the complexity of procedures consistent with the size of the business. Greater complexity could mean greater difficulty in adaptation to or accepting changes of the FSMS. Guidelines knowledge is related to the specific know-how the FBO has as to what official controls require to comply with the FSMS when a procedure is simplified. In this sense, it would be important to disseminate chain-specific guidelines to all FBOs (EC, 2005a), e.g., the guides of good hygiene practices for the dairy chain provided at European level (FACEnetwork, 2016) or those made available by a group of various institutions of Piedmont (Tallone et al., 2016). Incorporating these aspects in future communication strategies could help to overcome the reluctance of some FBOs. Furthermore, to achieve this goal (i.e., increase adhesion), communication strategies should also focus on business trade associations, consultants, and official food inspectors.

\section{Conclusions}

Our case study shows the relevance of targeted interventions in affecting the perception, knowledge and, potentially, behavior: training of FBOs on hazards, FSMS, and its opportunities for simplification. The training initiatives strengthened FBO trust in the FSMS and in optimizing their procedures, with the added value of directing their limited resources to effective actions. Knowledge of the existence of a hazard is the first step to try to effectively contrast it; whereas inadequate knowledge of a hazard can divert attention away from the problem or, on the contrary, generates unnecessary spending of resources in terms of both time and money.

From a public health point of view, the challenge is to better orientate FSMS simplification towards objectives of health value coupled with greater operative simplicity for ensuring food safety. An improvement in the inherent professional skills of FBOs will result in a higher level of consumer health protection.

\section{References}

Angelillo IF, Viggiani NM, Rizzo L, Bianco A, 2000. Food handlers and foodborne diseases: knowledge, attitudes, and reported behavior in Italy. J Food Prot 63:381-5.

European Commission, 2003. Commission Recommendation of 6 May 2003 concerning the definition of micro, small and medium-sized enterprises, 361/2003/CE. In: Official Journal, L 124/36, 20/05/2003.

European Commission, 2004a. Regulation of the European Parliament and of the Council of 29 April 2004 on the hygiene of foodstuffs, 852/2004/CE. In: Official Journal, L 139/1, 30/04/2004.

European Commission, 2004b. Regulation of the European Parliament and of the Council of 29 April 2004 laying down specific hygiene rules for on the hygiene of foodstuffs, 853/2004/CE. In: Official Journal, L 139/55, 30/04/2004.

European Commission, 2004c. Regulation of the European Parliament and of the Council of 29 April laying down specific rules for the organisation of official controls on products of animal origin intended for human consumption, 854/2004/CE. In: Official Journal, L 139/206, 30/04/2004.

European Commission, 2005a. Guidance document. Implementation of procedures based on the HACCP principles, and facilitation of the implementation of the HACCP principles in certain food businesses.

European Commission, 2005b. Regulation of the European Parliament and of the Council 15 November 2005 on microbiological criteria for foodstuffs, 2073/2005/CE. In: Official Journal, L $338 / 1,22 / 12 / 2005$.

European Commission, 2011.
DG(SANCO)/2010-6150 - MR FINAL: General report of a mission series carried out in six member states in the period November 2009 to March 2010 in order to gather information regarding the application of the hygiene regulations in small establishments producing meat and meat products of mammals and dairy products. Available from: http://ec.europa.eu/food/auditsanalysis/overview_reports/details.cfm?r ep_id=15. Accessed: Dec 2019.

European Commission, 2016. Commission Notice on the implementation of food safety management systems covering prerequisite programs (PRPs) and procedures based on the HACCP principles, including the facilitation /flexibility of the implementation in certain food businesses, 4608/2016/C. In: Official Journal, C 278/1, 30/07/2016.

European Food Safety Authority, 2017. Panel on Biological Hazards (BIOHAZ): Ricci A, Chemaly M, Davies R, Fernández Escámez PS, Girones R, Herman L, Lindqvist R, Nørrung B, Robertson L, Ru G, Simmons M, Skandamis P, Snary E, Speybroeck N, Ter Kuile B, Threlfall J, Wahlström H, Allende A, Barregård L, Jacxsens L, Koutsoumanis K, Sanaa M, Varzakas T, Baert K, Hempen M, Rizzi V, Van der Stede Y, Bolton D. Hazard analysis approaches for certain small retail establishments in view of the application of their food safety management systems. EFSA J 15:e04697.

Farmhouse and Artisan Cheese and Dairy Producers's European network, 2016. European guide for Good Hygiene Practices in the production of artisanal cheese and dairy products. Available from:

https://ec.europa.eu/food/safety/biosafet y/food_hygiene/guidance_en Accessed: Dec 2019.

Fielding LM, Ellis L, Beveridge C, Peters AC, 2005. An evaluation of HACCP implementation status in UK small and medium enterprises in food manufacturing. Int J Environ Health Res 15:117-26.

Food and Agriculture Organization of the United Nations, World Health Organization, 2006. FAO/WHO guidance to governments on the application of HACCP in small and/or less-developed food businesses. Available from: http://www.fao. org/docrep/009/a0799e/a0799e00.HTM Accessed: Dec 2019.

Henson S, Holt G, Northen J, 1999. Costs and benefits of implementing HACCP in 
the UK dairy processing sector. Food Control 10:99-106.

Karabasil N, Boskovic T, Dimitrijevic M, Vasilev D, Teodorovic V, Ilic N, Djordjevic V, 2015. Food hygiene Flexibility in traditional and small meat establishments. Procedia Food Sci 5:140-3.

Ko WH, 2013. The relationship among food safety knowledge, attitudes and selfreported HACCP practices in restaurant employees. Food Control 29:192-7.

Nicolandi L, Barzanti P, Enrico D, Gherardi P, Osella MC, Marino C, Ru G, 2012. Indagine campionaria sull'applicazione dei piani di autocontrollo tra gli operatori delle microimprese del settore lattierocaseario in Piemonte. Argomenti S.I.Ve.M.P. 14:57-61. Available from: https://sivemp.it/post_rivista/argomentinr-1-2012-anno-xv. Accessed: Dec 2019.

Nicolandi L, Barzanti P, Enrico D, Gherardi P, Osella MC, Ru G, 2011a. Indagine campionaria tra gli operatori del settore alimentare carni trasformate. Sintesi dei risultati. In Technical and scientific newsletter of the Piedmont RegionMedicina Veterinaria Preventiva 35:505.

Nicolandi L, Barzanti P, Enrico D, Gherardi
P, Osella MC, Ru G, 2011b. Indagine campionaria tra gli operatori del settore alimentare lattiero-caseario. Sintesi dei risultati. In Technical and scientific newsletter of the Piedmont RegionMedicina Veterinaria Preventiva 35:5662.

Panisello PJ, Quantick PC, 2001. Technical barriers to Hazard Analysis Critical Control Point (HACCP). Food Control 12:165-73.

Panisello PJ, Quantick PC, Knowles MJ, 1999. Towards the implementation of HACCP: results of a UK regional survey. Food Control 10:87-98.

Piedmont Region, 2012. Determina Dirigenziali No. 692 of 15 October 2012. Definizione di linee di indirizzo per il controllo ufficiale nella microimpresa. In: Bollettino Ufficiale, No. 47, 22/11/2012. Available from: http://www.regione.piemonte.it/governo /bollettino/abbonati/2012/47/siste/index. htm Accessed: Dec 2019.

StataCorp, 2015. Stata Statistical Software: Release 14. College Station, TX: StataCorp LP.

Tallone G, et al. 2016. Guida di buona prassi igienica per $\mathrm{i}$ caseifici di azienda agricola. Available from: http://www.casarecasari.it/guida-dibuona-prassi-igienica-per-i-caseifici-di-a zienda-agricola-versione-2016.

Accessed: Dec 2019.

Taylor E, Kane K, 2005. Reducing the burden of HACCP on SMEs. Food Control 16:833-9.

Thaivalappil A, Waddell L, Greig J, Meldrum R, Young I, 2018. A systematic review and thematic synthesis of qualitative research studies on factors affecting safe food handling at retail and food service. Food Control 89:97-107.

Violaris Y, Bridges O, Bridges J, 2008. Small businesses e big risks: current status and future direction of HACCP in Cyprus. Food Control 19:439-48.

Yapp C, Fairman R, 2006. Factors affecting food safety compliance within small and medium-sized enterprises: implications for regulatory and enforcement strategies. Food Control 17:42-51.

Zanin LM, da Cunha DT, de Rosso VV, Capriles VD, Stedefeldt E, 2017. Knowledge, attitudes and practices of food handlers in food safety: an integrative review. Food Res Int 100:5362. 